\title{
Identification and characterization of an RNA molecule that copurifies with RNase $P$ activity from HeLa cells
}

\author{
Marcjanna Bartkiewicz, ${ }^{1}$ Heidi Gold, and Sidney Altman ${ }^{2}$ \\ Department of Biology, Yale University, New Haven, Connecticut 06520 USA
}

\begin{abstract}
An RNA molecule, 340 nucleotides in length and designated H1 RNA, copurifies with RNase P activity from extracts of HeLa cells or isolated HeLa cell nuclei. When the genomic DNA of various organisms is probed with H1 cDNA in Southern hybridization assays, only mammalian DNA gives a positive signal. The gene coding for H1 RNA in human cells is present in one to three copies per cell. The nucleotide sequence of H1 RNA, which shows little homology to the known sequences of its analogs from prokaryotes and yeast, can be drawn as a two-dimensional, hydrogen-bonded structure that resembles similar structures proposed for the RNA subunit of RNase $P$ from these other sources. Part of the hypothetical structure is virtually identical to structures that can be drawn for analogous RNAs from Saccharomyces cerevisiae, Schizosaccharomyces pombe, and S. octosporus.
\end{abstract}

[Key Words: HeLa cells; ribonucleoprotein; RNase P; tRNA processing]

Received November 1, 1988; revised version accepted January 31, 1989.

RNase $\mathrm{P}$, an endoribonuclease responsible for the biosynthesis of the $5^{\prime}$ termini of mature tRNA molecules from their precursors (Altman et al. 1986), was first identified in extracts of Escherichia coli (Altman and Smith 1971). Since then, similar enzymatic activities have been found in extracts of both prokaryotic and eukaryotic cells. In every case examined in detail, both RNases and proteases have been shown to inactivate the enzymatic activity [although some conflicting data have been reported in the cases of Xenopus laevis and spinach chloroplasts by Castano et al. (1986) and Wang et al. (1988), respectively]. These observations indicate that RNase P has both essential RNA and protein subunits. However, a unique RNA species with a demonstrable role in the catalytic activity of RNase $\mathrm{P}$ has been characterized from only a few prokaryotic organisms. The RNA subunit of RNase P from E. coli, Salmonella typhimurium, and Bacillus subtilis is responsible for the catalytic activity of RNase $P$ from those organisms. No such demonstration of catalytic activity or ability to reconstitute the RNase $\mathrm{P}$ holoenzyme in vitro has been reported for the homogeneous species of RNA that have been $\mathrm{pu}$ rified from RNase P from Schizosaccharomyces pombe (Krupp et al. 1986), Saccharomyces cerevisiae (J.-Y. Lee and D. Engelke, pers. comm.), Schizosaccharomyces octosporus (D. Soll and S. Zimmerle, pers. comm.), and Saccharomyces cerevisiae mitochondria (Miller and Martin 1983).

1Permanent address: Institute of Biochemistry and Biophysics, Polish Academy of Sciences, Warsaw, Poland.

${ }^{2}$ Corresponding author.
A crude preparation of RNase $P$ from HeLa cells has been described previously (Koski et al. 1976; Gold and Altman 1986). However, because of the low abundance and lability of the enzymatic activity from HeLa cells, further purification and study of its components has heretofore proved difficult.

We now report an improved procedure for the purification of RNase P from extracts of HeLa cells, which has facilitated the isolation of an RNA molecule, designated H1 RNA, that copurifies with enzymatic activity. Analysis of the nucleotide sequence of the RNA has led us to propose a model for the secondary structure of this RNA. This model resembles one for the RNA subunit of RNase P from prokaryotes (James et al. 1988) and also allows direct comparisons to be made with two-dimensional models of RNAs that copurify with RNase P activity from S. cerevisiae (J.-Y. Lee and D. Engelke, pers. comm.) and S. pombe (Krupp et al. 1986).

The isolation of the cDNA clone for H1 RNA has also allowed the determination of the approximate copy number of the gene for Hl RNA in the human genome and an estimate of its homology with DNA sequences from other genomes.

\section{Results}

Identification of an RNA that copurifies with RNase $P$ activity in extracts of HeLa cells

Several attempts have been made to purify RNase $P$ from mammmalian cells (Koski et al. 1976; Gold and 
Figure 1. Purification of RNase P by column chromatography on DEAE-Sepharose, velocity sedimentation through glycerol gradients, and sedimentation in a $\mathrm{Cs}_{2} \mathrm{SO}_{4}$ buoyant density gradient. The left-hand ordinate represents cleavage activity and the right-hand ordinate represents protein concentration in each panel. $(A \mid$ Elution profile of RNase $\mathrm{P}$ activity from a column of DEAE-Sepharose CL-6B, as described in Materials and methods. ( $\bullet$ ) RNase $\mathrm{P}$ activity; ( $\square$ ) protein concentration; solid line indicates $\mathrm{NH}_{4} \mathrm{Cl}$ concentration (see inner scale). (B) Distribution of RNase P activity in the first glycerol gradient. Sedimentation carried out as described in Material and methods. ( $\bullet$ RNase P activity; ( $)$ protein concentration. $(C)$ Distribution of RNase $P$ activity in the second glycerol gradient. $(\bullet)$ RNase P activity; ( $\mid$ ) protein concentration. $(D)$ Distribution of RNase $\mathrm{P}$ activity in a $\mathrm{Cs}_{2} \mathrm{SO}_{4}$ buoyant density gradient. Samples were prepared and analyzed as described in Materials and methods. (Bottom segment) Dashed line indicates RNase P activity; solid line indicates protein concentration. (Top segment) Solid line indicates buoyant density $(\mathrm{g} / \mathrm{ml}$ ). Arrowheads indicate buoyant densities of various molecular species as follows: $(\nabla) E$. coli tRNA ${ }^{\text {Tyr }} ;(\nabla)$ RNase $P$ from veal heart (Akaboshi et al. 1980). The bottom of all of the gradients shown is at the lefthand side of the graphs.

Altman 1986; Gold et al. 1988; Doersen et al. 1985; Castano et al. 1986). Whereas Koski et al. (1976) and Gold and Altman (1986) used purified nuclei as starting material, Doersen et al. (1985) found, as we have confirmed, that a sufficiently large amount of activity leaks out of nuclei during the initial stages of the preparation and that the whole-cell cytosol is actually a more promising source of material. The identification of the activity as being nuclear in origin, separate from a different activity found in the mitochondria, was based on the biochemical properties and relative yields of the activity in different subcellular fractions (Doersen et al. 1985). In separate experiments we have verified (Gold 1988) that RNase P activity, isolated either from the whole-cell cytosol or from isolated nuclei, has identical biochemical properties and behaves identically during the first steps of purification, and now we have devised a procedure that allows us to purify the enzyme more than 1000-fold from the cytosol.

An extract (S20) of HeLa cells was fractionated on a column of DEAE-Sepharose, and those fractions that contained the peak of RNase P activity were concentrated as described in Materials and methods (Fig. 1A). This material then was purified further by velocity sedimentation through successive glycerol gradients (Fig. $1 \mathrm{~B}, \mathrm{C})$. The peak of enzymatic activity has a sedimentation coefficient of $\sim 15$ (Lawrence et al. 1987; Gold 1988). The distribution of enzymatic activity in the gradient and the RNA in the relevant fractions are shown in Figure 2A. The species labeled $\mathrm{H} 1$ and $\mathrm{H} 2$ are of particular interest. [We have shown in separate experiments (Gold et al. 1988) that H2 RNA migrates as two species, called $\mathrm{H} 2 \mathrm{a}$ and $\mathrm{H} 2 \mathrm{~b}$, when subjected to electrophoresis in a $5 \%$ polyacrylamide gel that contains $7 \mathrm{M}$ urea.] $\mathrm{H} 1$ RNA and H2 RNA copurify with and are enriched to the same extent as the enzymatic activity. No $\mathrm{H} 1$ or $\mathrm{H} 2$ RNA was found unassociated with the enzymatic ac-
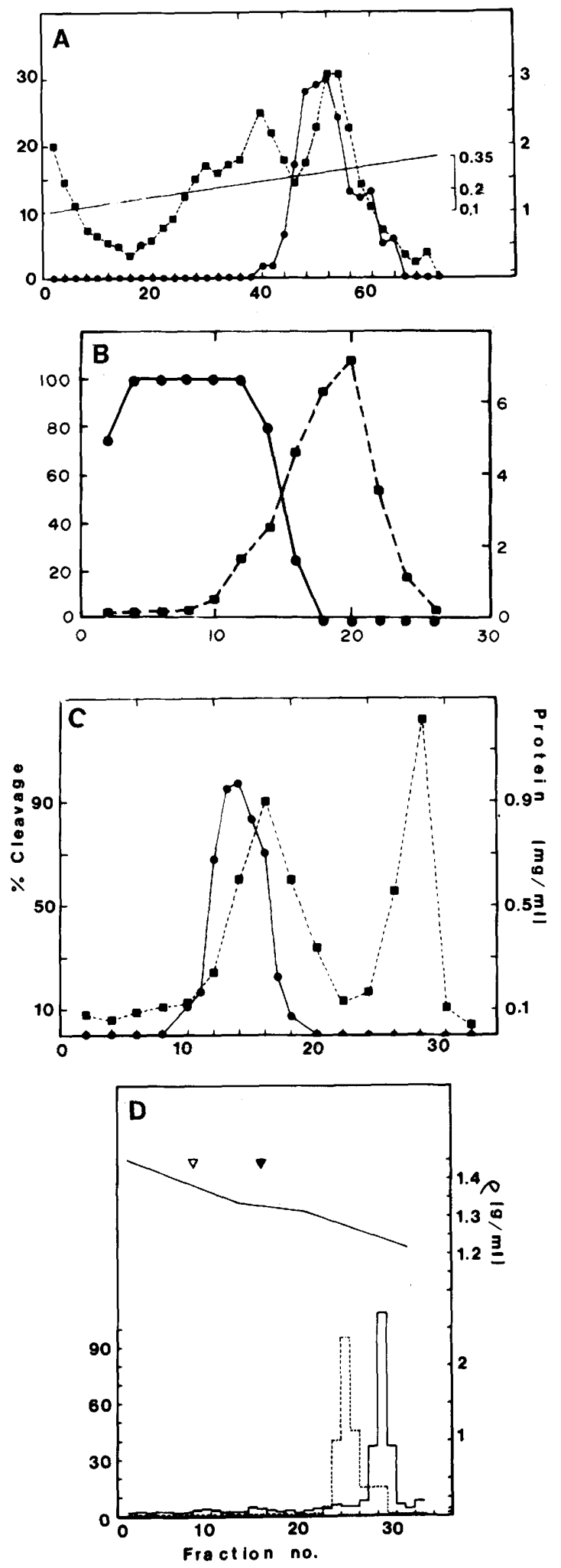

tivity in the fractions resulting from this or other methods of purification.

Further purification of the enzymatic activity can be achieved by $\mathrm{Cs}_{2} \mathrm{SO}_{4}$ density gradient centrifugation (Fig. 1D). Analysis of the RNA in the peak of enzymatic ac- 

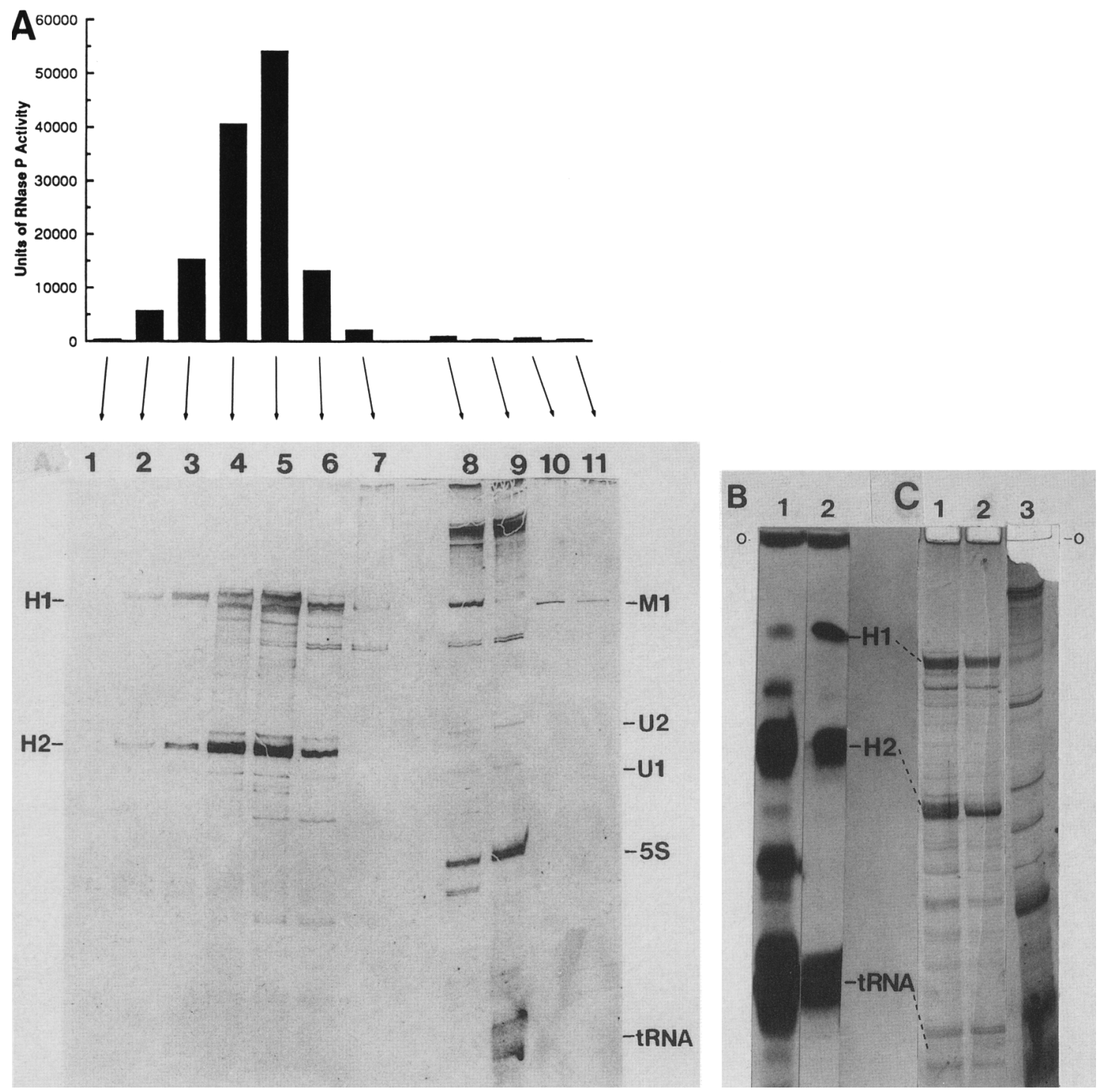

Figure 2. RNA species found in fractions containing RNase $\mathrm{P}$ activity at various stages of purification: $(A \mid$ Second glycerol gradient; $(B) \mathrm{Cs}_{2} \mathrm{SO}_{4}$ density gradient; $(C)$ Blue Agarose. Purification procedures are described in Materials and methods. The RNA shown in $A$ and $C$ was stained with silver; $B$ is an autoradiograph. $(A)$ (Top) The distribution of enzymatic activity in the gradient. (Lanes $1-7$, bottom to top of gradient) The RNA found in fractions across the peak of enzymatic activity in the second glycerol gradient activity. Maximum activity was found in lanes 4 and 5. (Lane 8) RNA in the samples from the peak of RNase P activity eluted from the column of DEAE-Sepharose loaded on the gradient; (lane 9) RNA in the S20 fraction; (lanes 10,11) 2.25 and 0.75 ng M1 RNA, respectively. The positions of various cellular RNAs, as well as $\mathrm{Hl}$ and $\mathrm{H} 2 \mathrm{RNA}$, are shown. $(B)$ RNA extracted from a glycerol gradient fraction (lane 1) loaded on a $\mathrm{Cs}_{2} \mathrm{SO}_{4}$ density gradient and RNA from the peak of enzymatic activity in the $\mathrm{Cs}_{2} \mathrm{SO}_{4}$ gradient (lane 2). The uppermost bands at the top of lanes 1 and 2 represent material that did not enter the gel at the origin of electrophoresis. $(C)$ RNA in the peak of enzymatic activity eluted from a column of Blue Agarose (lanes 1,2), in comparison with RNA in the S20 fraction (lane 3).

tivity $(\rho=1.28 \mathrm{~g} / \mathrm{ml})$ from a $\mathrm{Cs}_{2} \mathrm{SO}_{4}$ gradient (Fig. 2B) demonstrates the further enrichment of $\mathrm{H} 1$ and $\mathrm{H} 2$ RNAs, together with some contaminating tRNA, by this procedure. (Although tRNA is present in relatively low absolute amounts, by comparison with the H RNAs it is very efficiently labeled with RNA ligase and is over-represented in the autoradiograph.) RNase P also can be purified further after the glycerol gradients by chromatography on Blue Agarose. This step is effective in reducing contamination by the $\mathrm{U}$ small nuclear $(\mathrm{sn})$ RNAs and
tRNA, as shown in Figure 2C. In all the purification steps mentioned above, the amount of $\mathrm{H} 1$ and $\mathrm{H} 2$ RNA is well-correlated with the peaks of enzymatic activity, and these two species of RNA are the only ones that copurify with that activity. The final purification of activity, from the $\mathrm{S} 20$ through the $\mathrm{Cs}_{2} \mathrm{SO}_{4}$ step, is $\sim 1700$ fold (Table 1) when normalized in the standard fashion to the concentration of protein in the preparation.

We showed previously that $\mathrm{H} 1$ and $\mathrm{H} 2$ RNA can be purified even further from RNase $\mathrm{P}$ that was purified 
Table 1. Purification of RNase P from HeLa cells

\begin{tabular}{lccccrr}
\hline Step & $\begin{array}{l}\text { Volume } \\
(\mathrm{ml})\end{array}$ & $\begin{array}{l}\text { Units } \\
\left(\times 10^{-5}\right)\end{array}$ & $\begin{array}{l}\text { Protein } \\
(\mathrm{mg})\end{array}$ & $\begin{array}{l}\text { Specific } \\
\text { activity }\end{array}$ & $\begin{array}{l}\text { Yield } \\
(\%)\end{array}$ & $\begin{array}{l}\text { Fold } \\
\text { purification }^{\mathrm{c}}\end{array}$ \\
\hline S20 & 180 & 18 & 3800 & 0.47 & 100 & - \\
DEAE-Sepharose & 68 & 5.1 & 156 & 3.3 & 28 & 7 \\
glycerol gradient I & 30 & 3.8 & 13 & 30 & 21 & 17 \\
glycerol gradient II & 8.4 & 3.0 & 2.5 & 120 & 1.4 & 1700 \\
$\mathrm{Cs}_{2} \mathrm{SO}_{4}$ gradient & 0.26 & 0.25 & 0.03 & 800 & 255 \\
\hline
\end{tabular}

ane unit is defined as the amount of RNase P activity that cleaves $1 \%$ of tRNA precursor in 30 min at $37^{\circ}$ under standard assay conditions.

b Units/mg $\times 10^{-3}$.

c Based on specific activity calculated as shown above.

through the second glycerol gradient step by immunoprecipitation with sera from patients with autoimmune diseases. These sera precipitate $100 \%$ of the RNase P activity, and the pellets, from which enzymatic activity can be recovered, contain only $\mathrm{Hl}$ and $\mathrm{H} 2 \mathrm{RNA}$ (see Fig. 3B in Gold et al. 1988). Furthermore, similar immunoprecipitates from crude cell lysates contain only $\mathrm{H} 1$ RNA (1.3 $\mu \mathrm{g} / 3 \times 10^{8}$ cells $)$ and another RNA unrelated to RNase P activity found in a ribonucleoprotein complex that coprecipitates with RNase P (see Fig. 3 here and Fig. 2 in Gold et al. 1988). Only seven protein bands are apparent in SDS-polyacrylamide gel analysis of these immunoprecipitates from crude cell lysates (J.
Craft, pers. comm.). A rough estimate of the purification factor, based on the recovery of HI RNA and the protein in RNase $\mathrm{P}$ in the immunoprecipitates, compared to total RNA and protein in the crude cell extracts, yields a figure of $\sim 5000$. Nucleotide sequence analysis (see below) of H1 RNA extracted from partially purified preparations of RNase P (second glycerol gradient step) or immunoprecipitated from the crude cell lysates indicates that these two species are, indeed, identical. The precipitation of H1 RNA (and H2 RNA, in some cases) from both crude cell lysates and a partially purified preparation of RNase P activity is illustrated in Figure 3, in which the RNAs are identified by silver staining to

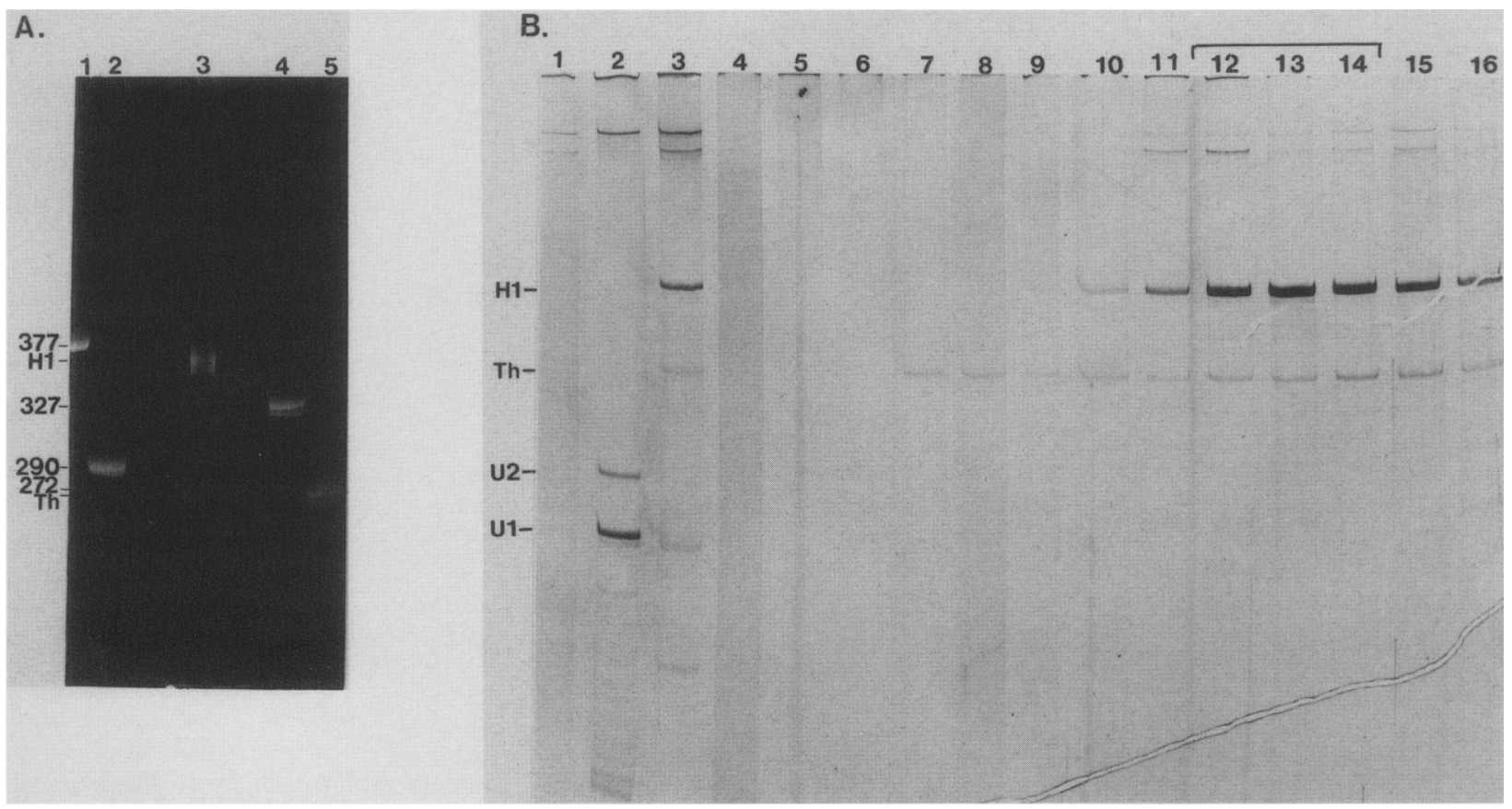

Figure 3. Analysis of RNA immunoprecipitated from a crude cell lysate $(A)$ and from RNase P purified through the DEAE-Sepharose step (B). In both cases, material was immunoprecipitated with anti-RNase P serum (Gold et al. 1988), extracted from the pellet, analyzed in a polyacrylamide gel and visualized by ethidium bromide $(A)$ or silver staining $(B)$. $(A)($ Lanes $1,2,4,5)$ Marker RNAs, with the sizes (in nucleotides) indicated at left; (lane 3) RNAs (H1 and Th) found in the pellet of the immunoprecipitate. (B) (Lane 1) Material immunoprecipitated from a crude cell extract with normal human serum; (lane 2) RNA immunoprecipitated from a crude cell extract with anti-Sm serum; (lane 3) RNA precipitated from a crude cell extract with anti-RNase P serum; (lanes 4-16) RNA immunoprecipitated from every third fraction eluted from a DEAE-Sepharose column (see Materials and methods) through the peak of enzymatic activity (shown by bar over lanes 12-14). Fractions eluted with high salt concentrations that contained no RNase $P$ activity did not contain $\mathrm{H1}$ or H2 RNA. Note that Th RNA, present in some DEAE fractions, does not copurify with H1 RNA in this or successive steps (Fig. 2). Some RNA that precipitates in a nonspecific manner is also visible in lanes 1-3. 
avoid the problem of disporportionate representation as a result of selective radiochemical labeling with ${ }^{32} \mathrm{P}$ $\mathrm{pCp}$. Thus, there is a strong correlation between the amount of enzymatic activity fractionated by classical biochemical methods or by immunoprecipitation from partially purified or crude cell fractions and the identity of the copurifying RNA species, H1 RNA.

It was noted previously that immunoprecipitates of RNase P from crude cell lysates contain H1 RNA and no H2 RNA. Additionally, fresh, partially purified preparations of the enzyme have a very low proportion of, or no, $\mathrm{H} 2$ (H2a plus H2b) RNA to H1 RNA compared to preparations at a later stage of purification or after storage (Gold et al. 1988). Accordingly, the hypothesis that H2a and $\mathrm{H} 2 \mathrm{~b}$ may be breakdown products of $\mathrm{H} 1$ RNA was investigated.

\section{Nucleotide sequence and cDNA cloning of H1 RNA}

RNA was extracted from RNase $P$ purified through the second glycerol gradient step and fractionated further through a $5 \%$ polyacrylamide gel that contained $7 \mathrm{M}$ urea. Bands corresponding to $\mathrm{H} 1 \mathrm{RNA}$ and $\mathrm{H} 2 \mathrm{a}$ and $\mathrm{H} 2 \mathrm{~b}$ RNA were extracted from the gel and each of these three purified RNAs was end-labeled with ${ }^{32} \mathrm{P}-\mathrm{pCp} \mid 3^{\prime}$ terminus). The nucleotide sequences proximal to the $3^{\prime}$ ends of the labeled RNAs were determined by the method of Donis-Keller et al. (1977). The RNA sequencing data also provided the necessary information to direct the synthesis in vitro of oligodeoxyribonucleotides that could be used as primers for further extensive sequence analysis by primer extension and for the synthesis of cDNA (Fig. 4). Accordingly, a primer complementary to the $3^{\prime}$ terminus of H1 RNA was employed to generate almost full-length cDNA, which subsequently was shown to have the sequence anticipated from the analysis of the RNA sequence. RNA sequence analysis already had determined the $3^{\prime}$ end of H2b RNA /at C168, see Figs. 4 and 5) and, therefore, the potential breakpoint in $\mathrm{Hl}$ RNA that leads to the production of $\mathrm{H} 2 \mathrm{a}$ and $\mathrm{H} 2 \mathrm{~b}$ RNAs. Additionally, using the oligodeoxyribonucleotides available (open boxes, Fig. 4), we showed by primer

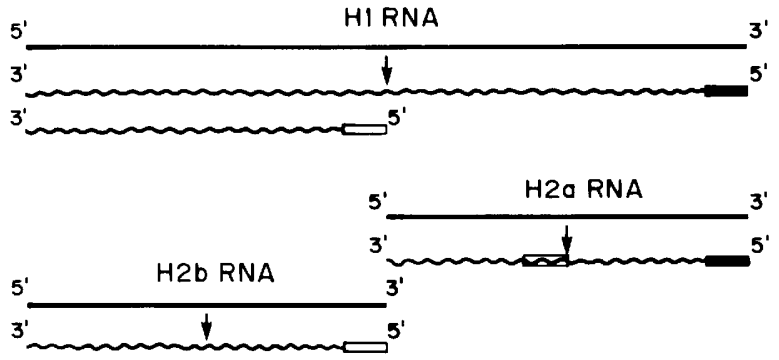

Figure 4. Schematic diagram of the relationship between $\mathrm{Hl}$, $\mathrm{H} 2 \mathrm{a}$, and H2b RNAs. Solid lines indicate the relative size and position of the RNA species. Boxes indicate the positions of priming oligonucleotides, the compositions of which were determined by RNA sequence analysis as described in Materials and methods, to prime reverse transcription (wavy lines).
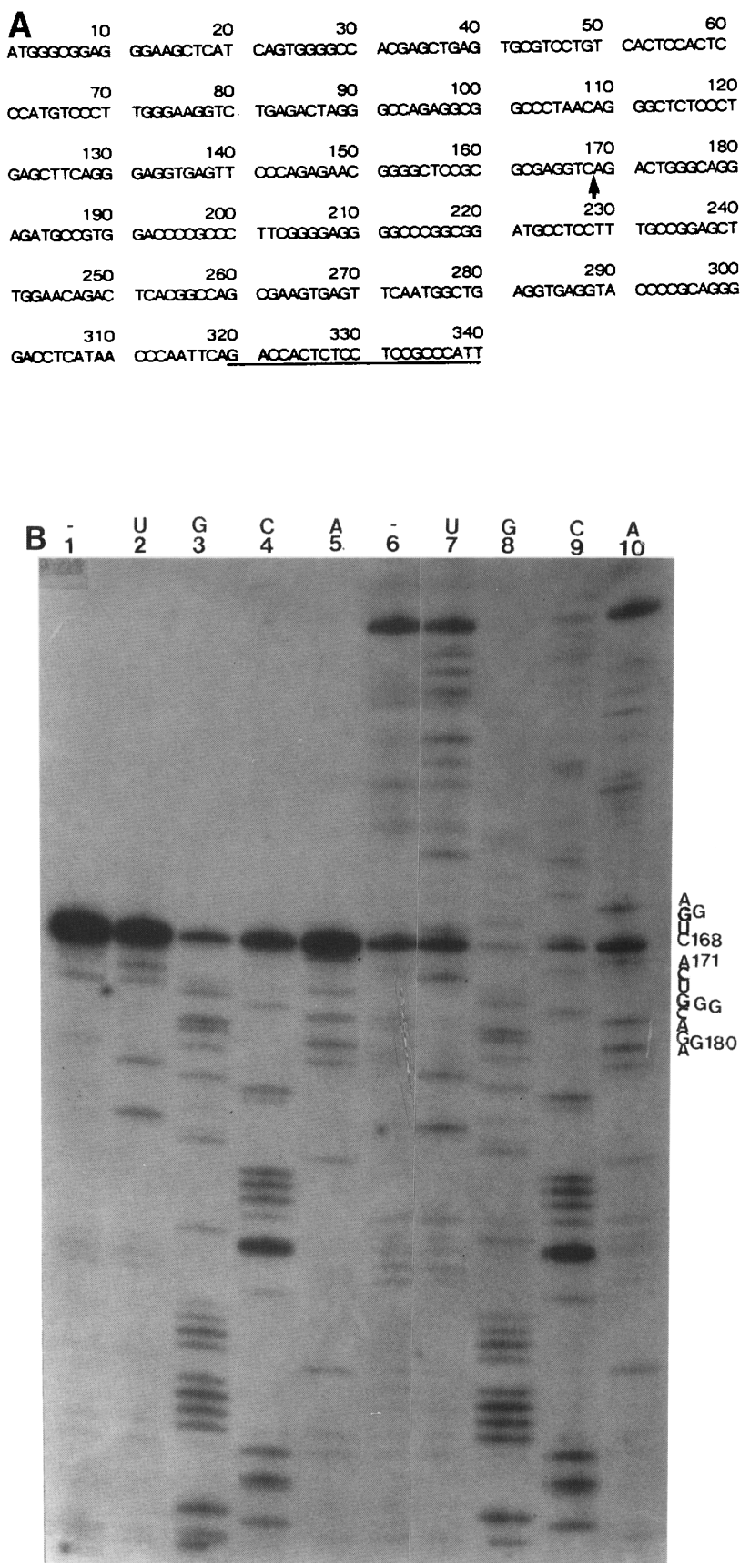

Figure 5. $(A \mid$ Nucleotide sequence of H1 DNA, as determined from the cDNA sequence, with the boundary in the corresponding RNA between $\mathrm{H} 2 \mathrm{a}$ and $\mathrm{H} 2 \mathrm{~b}$ RNAs indicated by the solid arrow. The underlined part of the sequence was determined by RNA sequence analysis. (B) Autoradiograph of an RNA sequencing gel showing the homology between H2a RNA (lanes 1-5) and H1 RNA (lanes 6-10). The primer near the center of H2a RNA (Fig. 4) was used to prime reverse transcription in order to check the location of the break point in $\mathrm{Hl}$ RNA. The reactions were carried out as described in Materials and methods: (Lanes 1,6) Reactions in the absence of dideoxynucleotide triphosphates; (lanes 2-5,7-10) appropriate dideoxynucleotide triphosphates were included in the reaction mixtures. Letters above the lane numbers refer to bases in the RNA sequence. Only part of the HI RNA sequence upstream from the breakpoint is shown. 

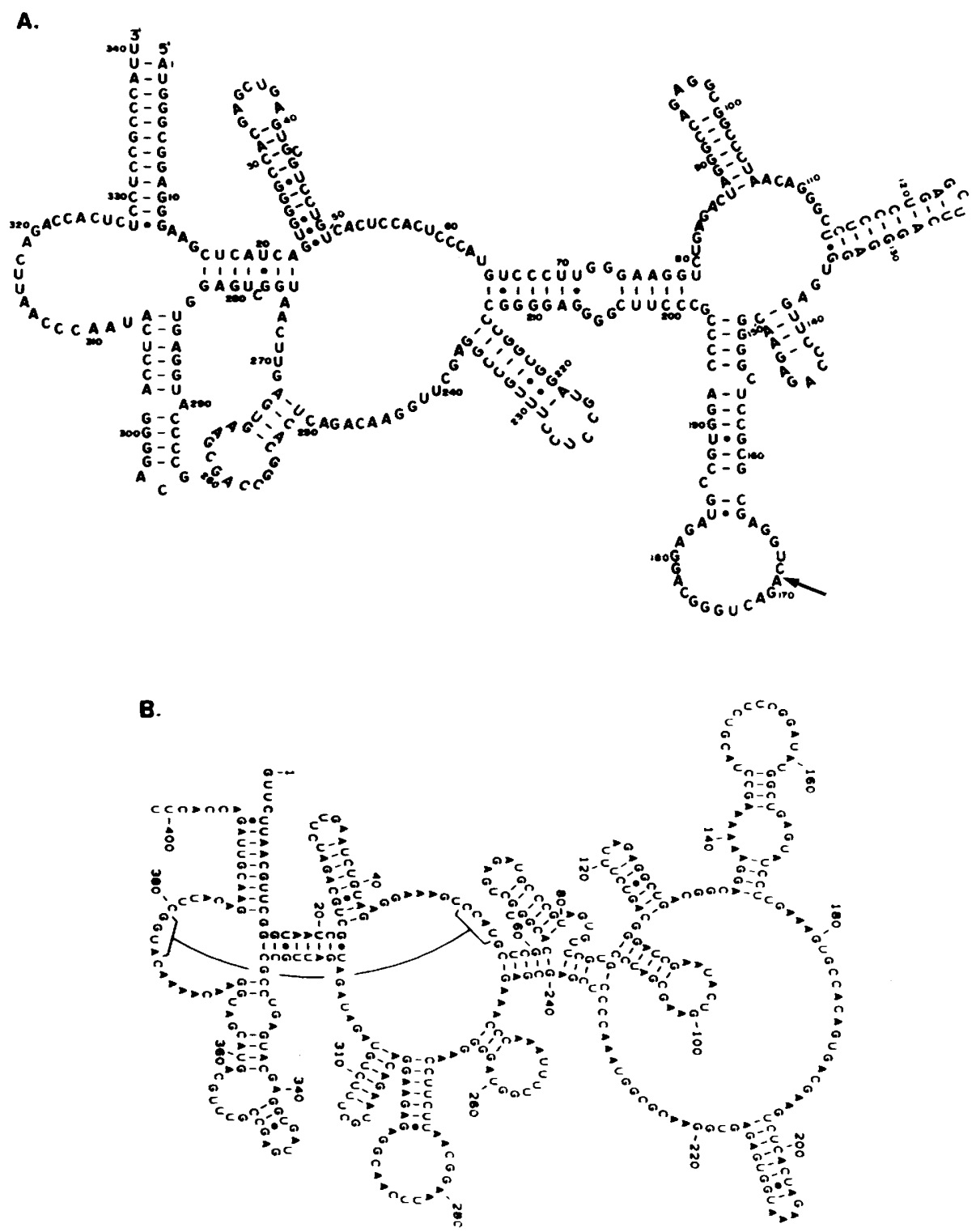

Figure 6. (A) A model for the secondary structure of H1 RNA. The arrow indicates the boundary between H2a and H2b RNAs. (B) A model for the secondary structure of P-RNA from B. subtilis (reprinted, with permission, from James et al. 1988).

extension that the sequence near the $5^{\prime}$ end of H2a RNA corresponds to that of Hl RNA at the proposed breakpoint though the sequencing gel cannot resolve positions 169 and 170. Nevertheless, estimates in sequencing gels of the size of H2a RNA are consistent with the location of the break point (and $3^{\prime}$ end of H2b RNA), as shown in Figure 4.

The cDNA corresponding to Hl RNA was inserted into the pUC19 vector, as described in Materials and methods. Using a 21 -mer and a 19-mer as probes (see Fig. 4), we selected clones containing the insert by colony hybridization after transformation. The clones were purified and the cDNA sequence was determined (Fig. 5), as described in Materials and methods. This analysis showed that three nucleotides from the $3^{\prime}$ end of the RNA were missing in the cloned cDNA when its sequence was compared with that of Hl RNA. Rigorous identification of 21 nucleotides at the $3^{\prime}$ end of the $\mathrm{H} 1$ sequence, therefore, was made from the analysis of the RNA sequence. The first nucleotide at the $5^{\prime}$ end of $\mathrm{Hl}$ RNA was found to be the same in the analyses of both the DNA and RNA sequences. Hl RNA does not have a cap structure at its $5^{\prime}$ terminus (data not shown).

\section{A model for the secondary structure of H1 RNA}

Several models have been proposed for the secondary structure of the RNA subunit of RNase P from prokaryotes, S. cerevisiae and S. pombe (Krupp et al. 1986; Lawrence et al. 1987; James et al. 1988; J.-Y. Lee and D. Engelke, pers. comm.). Although the DNA corresponding to, e.g., Ml RNA from E. coli, does not hybridize in Southern blot assays with total DNA from HeLa cells (Gold and Altman 1986; Gold 1988), one 
might expect that the structure in solution and the secondary structure of $\mathrm{Hl}$ RNA would resemble that of Ml RNA and its analogs, if $\mathrm{Hl}$ has a role in the function of RNase P from HeLa cells. A model for the secondary structure of Hl RNA was devised with two initial premises: (1) that the $5^{\prime}$ and $3^{\prime}$ termini would be hydrogen bonded, as they are in prokaryotic analogs and in many other stable RNAs; and (2) that the resulting structure would show some similarity to the one proposed for the prokaryotic analogs of M1 RNA if, indeed, H1 RNA represented the human analog, and that it might also be useful for constructing models of the yeast analogs. With these constraints, we generated the structure shown in Figure 6A: The resemblance to the structure proposed by James et al. (1988) for P-RNA, the analog (Fig. 6B) from B. subtilis, is apparent.

A comparison of models of secondary structures of different RNA molecules may not be very informative in terms of the identification of sequences essential for functions if the sequences of the different RNAs have drifted far apart. Nevertheless, some success was achieved in preliminary sequence and structural comparisons between H1 RNA and its analog from S. pombe by A. Forster of our laboratory (pers. comm.). More extensive structural models for the portion of Hl RNA and its analogs from this and other yeasts that encompass the 5' - and 3'-terminal regions of the RNAs are shown in Figure 7. The similarities in structure and the location of conserved nucleotides at the same positions in the single-stranded regions provide strong circumstantial evidence that these molecules are related both in terms of ancestry and of function. It should be noted that the structural model shown is not exclusive. For example, nucleotides 269-271 in H1 RNA can be drawn hydrogen bonded to nucleotides $248-250$ rather than remaining unpaired, as shown. Because of the limited number of such sequences derived from eukaryotes to date, we have not yet been able to extend such an analysis to include the entire nucleotide sequences of these molecules with any great confidence.

Note that P-RNA from B. subtilis forms a structure very similar to the other structures shown in Figure 7 /as does MI RNA from E. coli; data not shown). An attempt to find the same 'conserved' nucleotides in P-RNA that are boxed in the other parts of Figure 7 was not very rewarding. Although some weak assignments are shown underlined in the Figure 7, such 'conserved' nucleotides cannot be identified readily in the prokaryotic RNA, presumably because $B$. subtilis is related more distantly to all the other organisms than they, themselves, are to each other. Substitution or deletion of some of these conserved nucleotides in M1 RNA does not abolish enzymatic activity completely (Guerrier-Takada and Altman 1986; Lumelsky and Altman 1988).

Homologies of the cDNA clone that encodes H1 RNA with genomic DNA from various organisms

DNA was extracted from human tissue and from several other organisms (see Materials and methods), treated with various restriction enzymes, subjected to electrophoresis in a $0.8 \%$ agarose gel and probed with $\mathrm{H} 1$ cDNA in a Southern blot hybridization assay. As shown in Figure 8A, H1 cDNA hybridizes to the DNA from hamster, mouse, and human tissue, as indicated by the bands in lanes 3-6. However, there is no hybridization to mitochondrial DNA from HeLa cells, E. coli, or any of the other eukaryotic DNAs probed, none of which are of mammalian origin. A comparison of the hybridization to human genomic DNA, extracted either from human peripheral blood leukocytes or HeLa cells, is shown in Figure $8 \mathrm{~B}$, lanes $2-7$. Note that some polymorphism is apparent in the EcoRI and HindIII digests of these total genomic DNAs (cf. lanes 2 with 5 and 3 with 6 ).

The relative intensity of the bands in lanes 3 and 5 of Figure 8B, which show multiple bands in complete digests, suggests that the copy number of the gene for $\mathrm{Hl}$ RNA in human cells is, at most, three /although we cannot exclude rigorously the possibility that it may be a multiple of three). The intensity of the signals in lane 1 of Figure 8A, in comparison with that in lane 8, also indicates that the copy number must be very low, perhaps as low as one.

\section{Discussion}

We have identified an RNA molecule in extracts of HeLa cells that copurifies with RNase P activity, and we have determined its nucleotide sequence. It has been shown previously that RNase P activity from HeLa cells is sensitive to inactivation by micrococcal nuclease (Koski et al. 1976; Gold and Altman 1986; Gold 1988). Additionally, the buoyant density of this activity is consistent with that of a nucleic acid-protein complex (Fig. 1D). Furthermore, several species of RNA were found in the crude preparation of RNase P from HeLa cells, none longer than 135 nucleotides, and it was suggested (Gold and Altman 1986) that these RNAs might be breakdown products of a larger molecule. We have now improved methods for the storage and preparation of RNase P, which enabled us to identify an RNA, 340 nucleotides long and designated H1 RNA, that copurified with the enzymatic activity. Concurrently with the work reported here, Gold et al. (1988) showed that antibodies in the serum from some patients with systemic lupus erythematosus and related rheumatic diseases precipitate RNase $\mathrm{P}$ activity from lysates of HeLa cells and from our partially purified preparations of RNase $P$. These immunoprecipitates from crude cell extracts contain only $\mathrm{H} 1$ RNA and another snRNA (Th), unrelated to RNase P activity, in common. Furthermore, the immunoprecipitates from partially purified RNase $P$ contain only one major species of RNA, namely H1 RNA, and, in some cases, also contain its breakdown products, $\mathrm{H} 2 \mathrm{a}$ and $\mathrm{H} 2 \mathrm{~b}$ RNA, each $\sim 170$ nucleotides in length. Molecules similar in size to H1 RNA have been found to copurify with RNase $\mathrm{P}$ activities from $S$. cerevisiae (J.-Y. Lee and D. Engelke, pers. comm.), S. pombe (Krupp et al. 1986), and S. cerevisiae mitochondria (Miller and Martin 1983). Although various pieces of indirect evidence indicate that 

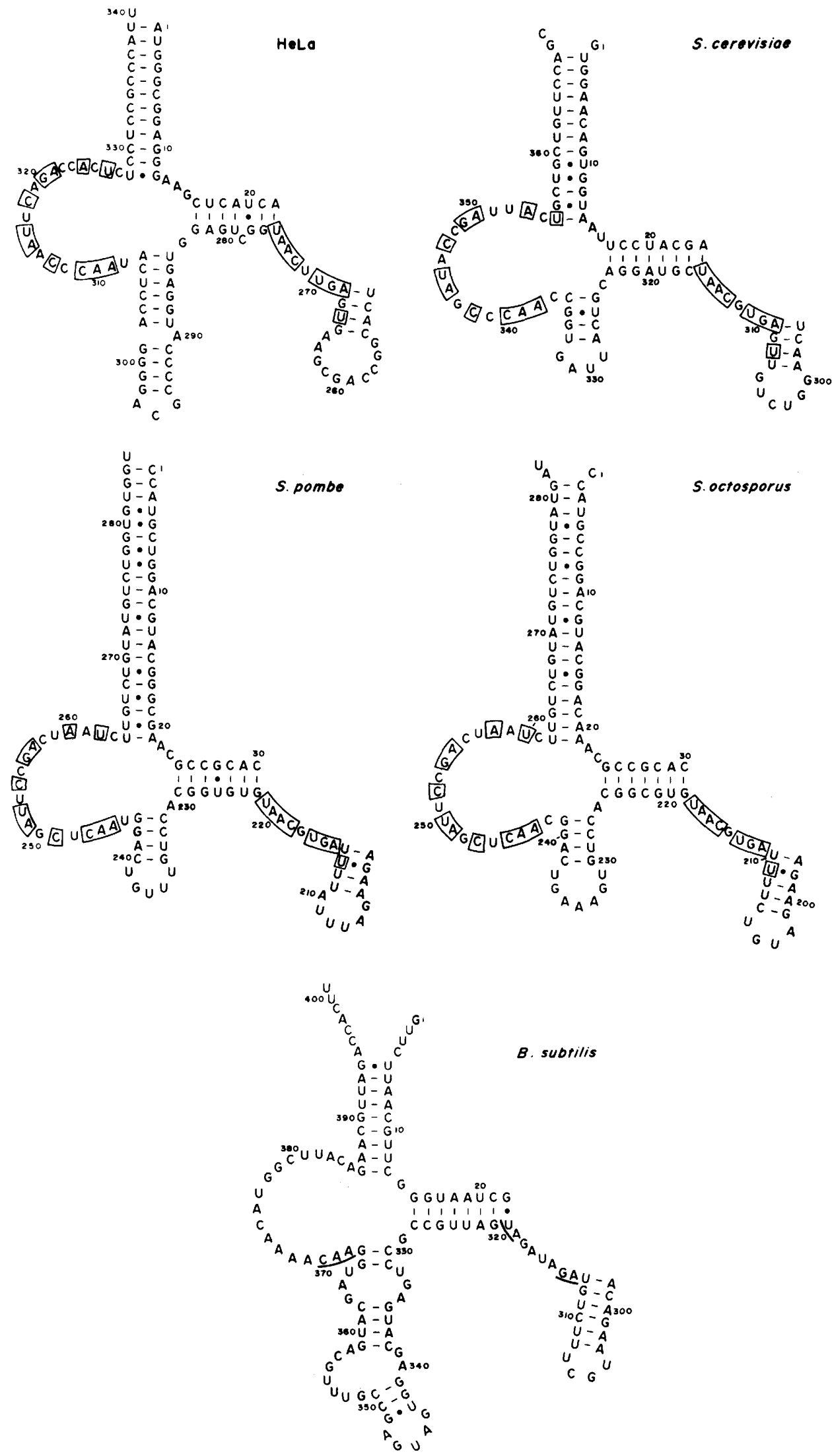

Figure 7. Comparison of the stem regions formed between the $5^{\prime}$ and $3^{\prime}$ ends of various analogs of H1 RNA. The boxed nucleotides show homologies at various positions. The underlined nucleotides in the model for P-RNA from $B$. subtilis show possible homologies with the boxed nucleotides in the other diagrams. 


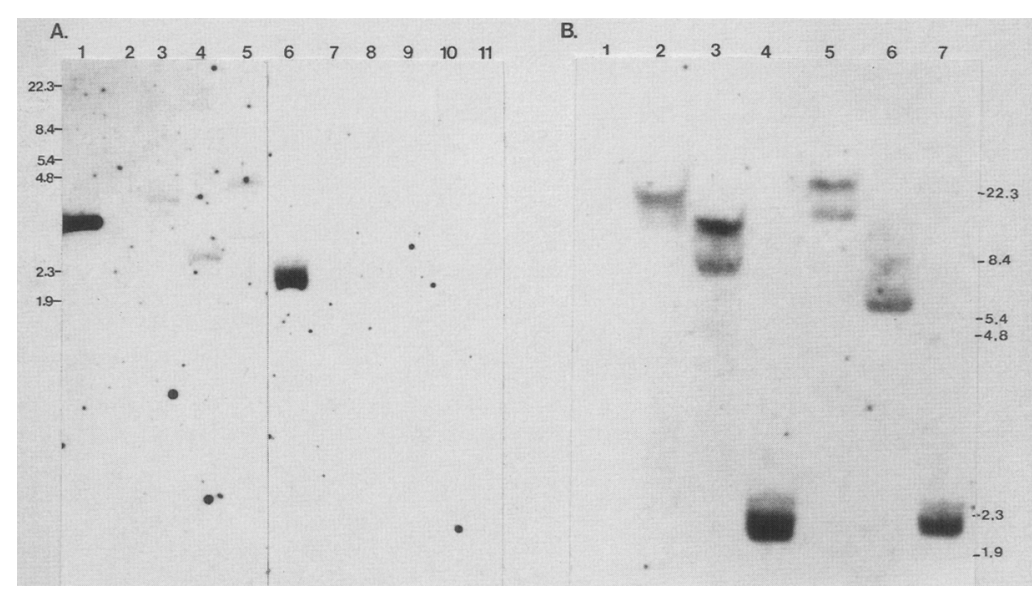
pGeml plasmid DNA (1 ng), digested with EcoRI; (lanes 2-4) human genomic DNA extracted from leukocytes (25 $\mu$ g), digested with EcoRI, HindIII, and PstI, respectively; (lanes 5-7) human genomic DNA, extracted from HeLa cells (25 $\mu \mathrm{g})$ and digested with EcoRI, HindIII, and PstI, respectively. (Left) Numbers indicate the size (in kilobases) of marker DNA generated by digestion of bacteriophage $\lambda$ DNA.

these RNA molecules are the RNA subunits of RNase P in the respective organisms, in none of these latter cases have these RNA molecules by themselves been reported to show any catalytic activity or any ability to function in reconstitution assays with protein in vitro. As in the case of the other eukaryotic analogs of $\mathrm{H1}$ RNA, first attempts to demonstrate directly a role for $\mathrm{Hl}$ RNA in the function of RNase $P$ in vitro have not yet met with success. Under a variety of experimental conditions, this RNA (prepared by transcription in vitro and containing 16 extra nucleotides at each end; see Material and methods), alone or in combination with the protein subunit of RNase P from E. coli, does not exhibit any catalytic activity. Further experiments to determine directly if H1 RNA plays an essential functional role in RNase P activity from HeLa cells is under way.

The holoenzyme from HeLa cells clearly is different from that from $E$. coli and B. subtilis in that it has a larger proportion of protein, by weight, as estimated from its buoyant density, velocity sedimentation, Western blotting (Gold 1988), and comparisons of the sizes of the RNA subunits. The only protein associated with RNase P from $E$. coli has a molecular mass of $\sim 13.8 \mathrm{kD}$, whereas preliminary experiments identify the protein antigen in the mammalian enzyme as having a molecular mass of $\sim 38 \mathrm{kD}$ (Gold et al. 1988; M. Baer, unpubl.). The molecular mass of the antigenic protein and the physical properties of the enzyme are not compatible with a $1: 1$ stoichiometry of protein and RNA in the HeLa enzyme. Thus, we conclude that the stoichiometry must be different from that found in the $E$. coli enzyme and/or there are protein subunits of different molecular weights in the HeLa enzyme. An association of H1 RNA with more than one protein may be indicative of either a greater range of functions of the holoenzyme in mammalian cells than is found in prokaryotes or a more complex control of the reaction than is required in prokaryotes. We also do not know whether $\mathrm{H} 1$ RNA contains modified nucleotides in vivo and whether the absence of such modifications and the extra nucleotides in the transcript made in vitro affects its function.

Notwithstanding the limited data on the function of H1 RNA in vitro, there is considerable evidence, in addition to the biochemical data, that this molecule is the analog in HeLa cells of the prokaryotic RNA subunit of RNase P. As in the case of its analogs from prokaryotes and yeast, $\mathrm{H} 1$ RNA only hybridizes to the genomic DNAs of closely related organisms, i.e., mammals. However, both the size and proposed secondary structure of H1 RNA are similar to that of its analogs in prokaryotes and yeasts. Indeed, the latter observation confirms the prediction, made on the basis of the absence of conservation of primary sequence but conservation of function across species lines, that all analogs of M1 RNA, the RNA subunit of RNase P from E. coli, should have similar secondary structures and similar conformations in solution (Guerrier-Takada et al. 1983; Gold and Altman 1986). In particular, the remarkable similarities of parts of the structural models shown in Figure 7 and the placement of conserved nucleotides therein are reminiscent of the similarities in structures and segments of sequence found among the prokaryotic analogs of $\mathrm{Ml}$ RNA (Lawrence et al. 1987; James et al. 1988), several of which have been proved to be the catalytic subunit of RNase P by direct experiment. Many of the remaining portions of the eukaryotic molecules shown in Figure 7 can be aligned with each other to create a common structure, but several regions of uncertainty still prevent the drawing of a complete picture of these molecules (G. McCorkle, pers. comm.).

\section{Materials and methods}

\section{Purification of RNase $P$}

Ten liters of a suspension culture of HeLa cells were harvested at the MIT Cell Culture Center, and the pellet $(\sim 25 \mathrm{~g})$ was received at Yale on wet ice. Special care was taken to ascertain that these cells were not contaminated with bacteria or fungi. 
All subsequent steps were carried out at $0-4^{\circ} \mathrm{C}$. All buffers were supplemented with $1 \mathrm{~mm}$ dithiothreitol (DTT) and 0.2 mM phenylmethylsulfonyl fluoride (PMSF).

A crude extract ( $\mathrm{S} 20$ fraction) of the HeLa cells was prepared essentially as described previously by Doersen et al. (1985). The $\mathrm{S} 20$ fraction ( $160 \mathrm{ml}$ ) was adjusted to a final buffer composition of $20 \mathrm{~mm}$ Tris- $\mathrm{HCl}$ (pH 7), $50 \mathrm{mM} \mathrm{NH}_{4} \mathrm{Cl}$, and $15 \mathrm{mM} \mathrm{MgCl}_{2}$. This material was loaded on a column of DEAE-Sepharose CL-6B (bed volume, $150 \mathrm{ml}$ ) that had been preequilibrated with buffer A [20 mM Tris- $\mathrm{HCl}$ (pH 7), $15 \mathrm{mM} \mathrm{MgCl}_{2}, 10 \%$ glycerol [vol/vol)] that contained $50 \mathrm{mM} \mathrm{NH} \mathrm{NH}_{4}$. The column was washed with five volumes of buffer $\mathrm{A}$ that contained $0.1 \mathrm{M}$ $\mathrm{NH}_{4} \mathrm{Cl}$, and the enzymatic activity was then eluted with a linear gradient of $0.1-0.35 \mathrm{M} \mathrm{NH}_{4} \mathrm{Cl}$ in 1 liter of buffer A. Fractions containing the peak of enzymatic activity (as determined by the assay procedure described by Guerrier-Takada et al. 1988 ) were pooled and concentrated to a final volume of $8 \mathrm{ml}$ on Amicon Centriflo concentrating filters (type CF 50A). Protein concentrations were determined by the method of Bradford (1976).

The concentrated fractions containing the peak of enzymatic activity were centrifuged at $35,000 \mathrm{rpm}$ for $23 \mathrm{hr}$ at $4^{\circ} \mathrm{C}$ in a Beckman SW 41 rotor. Approximately $1 \mathrm{ml}$ of the concentrated fractions was layered on each of six tubes that contained a linear glycerol gradient $(15-25 \% \mathrm{vol} / \mathrm{vol})$ in buffer G $[50 \mathrm{~mm}$ Tris- $\mathrm{HCl}(\mathrm{pH} 8), 100 \mathrm{mM} \mathrm{KCl}$, and $10 \mathrm{~mm} \mathrm{MgCl}_{2}$ ]. Fractions $[0.4$ ml) were collected through a needle at the bottom of each tube. Fractions containing the peak of enzymatic activity were pooled, concentrated as described above to a final volume of 1 $\mathrm{ml}$, layered on glycerol gradients in two tubes, and recentrifuged exactly as described above. The fractions containing the peak of enzymatic activity were concentrated through Amicon Centricon-30 Microconcentrators to a final volume of $1 \mathrm{ml}$ and stored at $0^{\circ} \mathrm{C}$. Further purification was carried out either by density-gradient centrifugation or by chromatography on a column of Blue Agarose.

Step density gradients of $\mathrm{Cs}_{2} \mathrm{SO}_{4}$ were prepared by layering $1.6 \mathrm{ml}$ each of 37,31 , and $25 \%$ (wt/vol) of $\mathrm{Cs}_{2} \mathrm{SO}_{4}$ in buffer $\mathrm{G}$ that contained $10 \%$ glycerol in $5-\mathrm{ml}$ tubes suitable for use with the Beckman SW 65 rotor. Concentrated enzyme $(0.1 \mathrm{ml})$ from the second glycerol gradient step was layered on a gradient, and centrifugation was carried out for $10 \mathrm{hr}$ at $59,000 \mathrm{rpm}$ at $4^{\circ} \mathrm{C}$. Fractions $(0.15 \mathrm{ml})$ were then collected as described above. Each fraction was assayed immediately for RNase P activity as described previously (Guerrier-Takada et al. 1988).

For chromatography on Blue Agarose, about one fifth of the volume of the concentrated enzyme from the second glycerol gradient step was diluted with an equal volume of $50 \mathrm{~mm}$ Tris$\mathrm{HCl}\left(\mathrm{pH} \mathrm{7.4)}\right.$ and $10 \mathrm{mM} \mathrm{MgCl}_{2}$ and loaded onto a column of Blue Agarose (bed volume, $0.5 \mathrm{ml}$ ), preequilibrated with buffer C [50 mM Tris- $\mathrm{HCl}$ (pH 7.4), $50 \mathrm{~mm} \mathrm{KCl}, 10 \mathrm{~mm} \mathrm{MgCl}_{2}, 10 \%$ glycerol (vol/vol)]. The column was washed with $5 \mathrm{ml}$ buffer $\mathrm{C}$, and the enzymatic activity eluted with $10 \mathrm{ml}$ of a linear gradient of $\mathrm{KCl}(0.05-2.0 \mathrm{M})$ in buffer $\mathrm{C}$. Fractions of $0.3 \mathrm{ml}$ were collected, and RNA was extracted with phenol.

\section{Analysis of RNA in fractions that contained RNase P activity}

RNA was extracted with phenol, lyophilized, and washed with $75 \%$ ethanol or precipitated in ethanol with $20 \mu \mathrm{g} / \mathrm{ml}$ oyster glycogen (Boehringer-Mannheim) as carrier. Samples were prepared for electrophoresis as described previously (Guerrier-Takada and Altman 1984). Electrophoresis was carried out in $8 \%$ polyacrylamide gels that contained $7 \mathrm{M}$ urea. Gels were stained with silver (Goldman and Merril 1982), as described by Gold (1988). In some cases, RNA was labeled with ${ }^{32} \mathrm{P}$-pCp prior to electrophoresis and, subsequently, gels were subjected to autoradiography.

\section{Preparation of $H 1$ and $H 2$ RNA}

RNA was extracted from RNase $P$, purified through the second glycerol gradient step, precipitated as described above, and subjected to electrophoresis through a $5 \%$ polyacrylamide gel that contained $7 \mathrm{M}$ urea. RNA species were visualized by staining with ethidium bromide, and the bands that corresponded to $\mathrm{HI}$ and H2 RNA were cut out, and the RNA was eluted by the procedure described by Guerrier-Takada and Altman (1984).

\section{Analysis of nucleotide sequences}

$\mathrm{Hl}$ and H2 RNA were prepared as described above, labeled at their $3^{\prime}$ termini with ${ }^{32} \mathrm{P}-\mathrm{pCp}$ (Englund et al. 1980), and purified by electrophoresis through a $5 \%$ polyacrylamide gel that contained $7 \mathrm{M}$ urea. The labeled, purified RNAs were treated with RNase $T_{1}$ under conditions for mild digestion and the products were separated in a $20 \%$ polyacrylamide gel that contained $7 \mathrm{M}$ urea. The nucleotide sequences of the labeled end product of digestion by RNase $T_{1}$ and of successively larger oligonucleotides were determined by the methods of Donis-Keller et al. (1977), employing RNases $T_{1}$, U2, Phy M, and CL3. In this way, at least 30 nucleotides proximal to the $3^{\prime}$ end of each species was determined. The nature of the $3^{\prime}$ terminal nucleotide was determined by digestion of a labeled oligonucleotide with RNase $T_{2}$, followed by electrophoresis of the digest on $3 \mathrm{M}$ paper with suitable markers, as described by Brownlee (1972). To determine the 5 '-terminal nucleotide of H1 RNA isolated from HeLa cells, the RNA was treated with calf intestinal phosphatase, $5^{\prime}$-end labeled with $\left[\gamma^{-32}\right.$ P]ATP, using T4 polynucleotide kinase, purified by electrophoresis through a $5 \%$ polyacrylamide gel that contained $7 \mathrm{M}$ urea, and then digested to completion with nuclease P1. The digest was then analyzed by two-dimensional thin-layer chromatography (Nishimura 1972), as described by Guerrier-Takada et al. (1988). Further analysis of sequences adjacent to the $5^{\prime}$ terminus of $\mathrm{Hl}$ RNA was carried out using $5^{\prime}$-end-labeled RNA, prepared as described above, and sequence-specific nucleases were employed in the same fashion as in the case of analysis of $3^{\prime}$-end-labeled Hl RNA.

The sequences of $\mathrm{Hl}$ and $\mathrm{H} 2 \mathrm{RNA}$ were completed using reverse transcriptase and a primer-extension technique (Tabler et al. 1985). Oligodeoxyribonucleotides corresponding to $21 \mathrm{nu}-$ cleotides at the $3^{\prime}$ end of $\mathrm{HI}$ RNA, 21 nucleotides near the center of H2a RNA, and 19 nucleotides at the $3^{\prime}$ end of $\mathrm{H} 2 \mathrm{~b}$ RNA (as shown in Fig. 3) were prepared by DNA synthesis using an Applied Biosystems DNA synthesizer. The procedure used for end labeling of the primers and extension with AMV reverse transcriptase (Promega) has been described previously (Tabler et al. 1985).

Sequencing of fragments of plasmid DNAs (see below) was carried out using the dideoxynucleotide chain-termination procedure (Sanger et al. 1977), employing modified T7 DNA polymerase (Sequenase, U.S. Biochemical Corp.).

\section{Synthesis of cDNA and cloning procedures}

H1 RNA $(0.5 \mu \mathrm{g})$, purified in a $5 \%$ polyacrylamide gel that contained $7 \mathrm{M}$ urea, was denatured by incubation for $10 \mathrm{~min}$ at room temperature in $5 \mu \mathrm{l}$ of $12 \mathrm{~mm}$ methylmercuric hydroxide. Two microliters of $400 \mathrm{~mm} \beta$-mercaptoethanol were added, and incubation was continued for $5 \mathrm{~min}$. The denatured RNA was then mixed with $2 \mu \mathrm{g}$ of oligodeoxyribonucleotide primer, com- 
plementary to the $3^{\prime}$ end of H1 RNA (see text and Fig. 3), which had been phosphorylated at its $5^{\prime}$ terminus. The synthesis of double-stranded cDNA was then carried out in the presence of $\left[\alpha{ }^{-32}\right.$ P]dCTP (Gubler and Hoffman 1983), using a cDNA synthesis system purchased from Amersham Radiochemicals (with the exception that $\beta$-mercaptoethanol replaced DTT in the 'first strand reaction mixture'). cDNA was extracted with phenol and purified by two precipitations with ethanol from 2 $M$ ammonium acetate and one precipitation from $0.3 \mathrm{M}$ sodium acetate. The final pellet of cDNA was washed with $75 \%$ ethanol and then lyophilized.

The cDNA was inserted into a pUC19 vector as follows: Phosphorylated EcoRI linkers (New England Biolabs) were ligated to the blunt-ended, double-stranded cDNA, using T4 DNA ligase (New England Biolabs), and then digested with EcoRI. The resulting cDNA product was extracted with phenol, precipitated with ethanol in the presence of oyster glycogen, and purified in a $5 \%$ polyacrylamide gel. The purified cDNA was ligated to pUC19 DNA, cut previously with EcoRI, and dephosphorylated with calf intestinal phosphatase (BoehringerMannheim). The resulting vector DNA, containing the cDNA insert, was used to transform $E$. coli DH5 $\alpha$, made competent by the method of Hanahan (1983). The H1 DNA insert also was subcloned into the pGeml vector (Promega Biotech) after digestion of the respective DNAs with EcoRI, and the resulting subclone was called pGem1-H1.

\section{Screening of transformed cells for recombinant DNA clones}

Transformed colonies were picked and grown in liquid culture: $0.1 \mathrm{ml}$ of each of these cultures were spotted onto nitrocellulose filters, and the filters were prepared for hybridization by the procedures described by Maniatis et al. (1982). Hybridization was performed overnight at $37^{\circ} \mathrm{C}$ in a sealed plastic bag that contained $5.5 \mathrm{ml}$ of $6 \times \mathrm{SSC}, 10 \times$ Denhardt's solution (Maniatis et al. 1982), and $5 \times 10^{6} \mathrm{cpm}$ of DNA probe. Two oligodeoxyribonucleotides $(21$ nucleotides complementary to the $3^{\prime}$ end of H1 RNA and 19 nucleotides complementary to the $3^{\prime}$ end of H2b RNA; see Fig. 3) were labeled, for use as probes, at their $5^{\prime}$ termini with $\left[\gamma^{-32} \mathrm{P}\right] \mathrm{ATP}$, using T4 polynucleotide $\mathrm{ki}$ nase (Maniatis et al. 1982). After hybridization, the filter was rinsed three times in $6 \times \mathrm{SSC}$ for $10 \mathrm{~min}$ at room temperature and then washed repeatedly for $30 \mathrm{~min}$ in $2 \times \mathrm{SSC}, 0.1 \%$ SDS, prewarmed for each wash at a different temperature. The final wash was performed with buffer at $60^{\circ} \mathrm{C}$.

\section{Southern hybridization assays}

Total genomic DNAs were digested with various restriction enzymes, subjected to electrophoresis in a $0.8 \%$ agarose gel, and transferred to nitrocellulose filters by the method of Southern (1975). Hybridizations were carried out at $42^{\circ} \mathrm{C}$ for 24 $\mathrm{hr}$ in $50 \%$ formamide, $5 \times$ SSC, $1 \times$ Denhardt's buffer (Maniatis et al. 1982), $1 \%$ SDS, $10 \%$ dextran sulfate, $100 \mu \mathrm{g} / \mathrm{ml}$ sheared salmon sperm DNA, and $2 \times 10^{6}$ to $4 \times 10^{6} \mathrm{cpm} / \mathrm{ml}$ of the DNA probe.

For use as a probe, the H1 DNA insert was excised from the pUC19-H1 plasmid DNA by digestion with EcoRI and purified by electrophoresis through a $5 \%$ polyacrylamide gel. The $\mathrm{H} 1$ DNA fragment then was labeled with $\left[\alpha-{ }^{32} \mathrm{P}\right] \mathrm{dCTP}$ to a sp. act. of $2 \times 10^{9} \mathrm{dpm} / \mu \mathrm{g}$, using the random primed DNA labeling kit (Boehringer-Mannheim). After hybridization, the nitrocellulose filters were rinsed twice at room temperature in $2 \times$ SSC and then washed twice at $65^{\circ} \mathrm{C}$ for $30 \mathrm{~min}$ in $1 \times$ SSC, $1 \%$ SDS.

\section{Acknowledgments}

We are very grateful to Drs. A. Bothwell, A. Hayday, and M. Mangin for their advice on cDNA cloning and to the members of our laboratory for many suggestions and encouragement. In particular, Drs. A. Forster and G.M. McCorkle provided valuable guidance in examining the proposed structures of HI RNA and its analogs from yeast. Dr. G. Attardi generously provided us with a gift of HeLa mitochondrial DNA, and several of our colleagues at Yale donated genomic DNA from various organisms. We are also grateful to Drs. D. Engelke and D. Soll for providing data prior to publication. This work was supported by grants from the U.S. Public Health Service and the U.S. National Science Foundation to S.A. H.A.G. was supported, in part, by a predoctoral training grant from the U.S. Public Health Service to Yale University, and M. Bartkiewicz was a fellow of the Rudolph Anderson Fund of the Graduate School of Yale University.

\section{References}

Akaboshi, E., C. Guerrier-Takada, and S. Altman. 1980. Veal heart ribonuclease $P$ has an essential RNA component. Biochem. Biophys. Res. Comm. 96: 831-837.

Altman, S. and I.D. Smith. 1971. Tyrosine tRNA precursor molecule polynucleotide sequence. Nature New Biol. 233: 3539.

Altman, S., M. Baer, C. Guerrier-Takada, and A. Vioque. 1986. Enzymatic cleavage of RNA by RNA. Trends Biochem. Sci. 11: $515-518$.

Altman, S., H.A. Gold, and M. Bartkiewicz. 1988. Ribonuclease $\mathrm{P}$ as a snRNP, In Structure and function of major and minor small nuclear ribonucleoprotein particles, (ed. M.L. Birnstiel), pp. 183-195. Springer-Verlag, Berlin, New York.

Bradford, M.M. 1976. A rapid and sensitive method for the quahntitation of microgram quantities of protein utilizing the principle of protein-dye binding. Anal. Biochem. 72: 248-254.

Brownlee, G.G. 1972. Determination of sequences in RNA. In Laboratory techniques in biochemistry and molecular biology, (ed. T.S. Work and E. Work), vol. 3. pp. 1-265. Elsevier, North-Holland, Netherlands.

Castano, J.G., R. Ornberg, J.G. Koster, J.A. Tobian, and M. Zasloff. 1986. Eucaryotic pre-tRNA $5^{\prime}$ processing nuclease: copurification with a complex cylindrical particle. Cell 46: 377-387.

Doersen, C.-I., C. Guerrier-Takada, S. Altman, and G. Attardi. 1985. Characterization of an RNase P activity from HeLa cell mitochondria. J. Biol. Chem. 260: 5942-5949.

Donis-Keller, H., A. Maxam, and W. Gilbert. 1977. Mapping of adenines, guanines and pyrimidines in RNA. Nucleic Acids Res. 4: 2527-2538.

Englund, T.E., A.G. Bruce, and O.C. Uhlenbeck. 1980. Specific labeling of 3' termini of RNA with T4 RNA ligase. Methods Enzymol. 65: 65-75.

Gold, H.A. 1988. Studies of RNase P from HeLa cells. Ph.D. thesis. Yale University, New Haven, Connecticut.

Gold, H.A. and S. Altman. 1986. Reconstitution of RNase P activity using inactive subunits from $E$. coli and HeLa cells. Cell 44: 243-249.

Gold, H.A., J. Craft, J.A. Hardin, M. Bartkiewicz, and S. Altman. 1988. Antibodies in human serum that precipitate Ribonuclease P. Proc. Natl. Acad. Sci. 85: 5483-5487.

Goldman, D. and C.R. Merril. 1982. Silver staining of DNA in polyacrylamide gels: linearity and effects of fragment size. Electrophoresis 3: 24-26. 
Gubler, V. and B.J. Hoffman. 1983. A simple and very efficient method for generating cDNA libraries. Gene 25: 263-269.

Guerrier-Takada, C. and S. Altman. 1984. Structure in solution of Ml RNA, the catalytic subunit of ribonuclease P from Escherichia coli. Biochemistry 23: 6327-6334.

1986. M1 RNA with large terminal deletions still retains its catalytic activity. Cell 45: 177-183.

Guerrier-Takada, C., K. Gardiner, T. Marsh, N. Pace, and S. Altman. 1983. The RNA moiety of ribonuclease P is the catalytic subunit of the enzyme. Cell 35: 849-857.

Guerrier-Takada, C., A. van Belkum, C.W.A. Pleij, and S. Altman. 1988. Novel reactions of RNase $P$ with a tRNA-like structure in Turnip Yellow Mosiac Virus. Cell 53: 267-272.

Hanahan, D. 1983. Studies on transformation of Escherichia coli with plasmids. I. Mol. Biol. 166: 557-580.

James, B.D., G.J. Olsen, J. Liu, and N.R. Pace. 1988. The secondary structure of ribonuclease P RNA, the catalytic element of a ribonucleoprotein enzyme. Cell 52: 19-26.

Koski, R., A. Bothwell, and S. Altman. 1976. Identification of ribonuclease $\mathrm{P}$-like activity from human $\mathrm{KB}$ cells. Cell 9: $101-116$.

Krupp, G., B. Cherayil, D. Frendeway, S. Nishikawa, and D. Soll. 1986. Two RNA species copurify with RNase P from the fission yeast Schizosaccharomyces pombe. EMBO J. 5: 1607-1703.

Lawrence, N.P., A. Richman, R. Amini, and S. Altman. 1987. Heterologous enzyme function in Escherichia coli and the selection of genes encoding the catalytic RNA subunit of RNase P. Proc. Natl. Acad. Sci. 84: 6825-6829.

Lumelsky, N. and S. Altman. 1988. Selection and characterization of randomly produced mutants in the gene coding for Ml RNA. J. Mol. Biol. 202: 443-454.

Maniatis, T., E.F. Fritsch, and J. Sambrook. 1982. Molecular cloning: A laboratory manual. Cold Spring Harbor Laboratory, Cold Spring Harbor, New York.

Miller, D.L. and N.C. Martin. 1983. Characterization of the yeast mitochondrial locus necessary for tRNA biosynthesis: DNA sequence and identification of a new transcript. Cell 34: 911-917.

Milligan, J., D. Groebe, G.W. Witherel, and O.C. Uhlenbeck. 1987. Oligoribonucleotide synthesis using T7 RNA polymerase and synthetic DNA templates. Nucleic Acids Res. 15: 8783-8798.

Nishimura, S. 1972. Minor components in transfer RNA: their characterization, location and function. Prog. Nucleic Acids Res. Mol. Biol. 12: 50-86.

Sanger, F., S. Nicklen, and A.R. Coulson. 1977. DNA sequencing with chain terminating inhibitors. Proc. Natl. Acad. Sci. 74: 5463-5467.

Southern, E. 1975. Detection of specific sequences among DNA fragments separated by gel electrophoresis. J. Mol. Biol. 98: $503-517$.

Tabler, M., M. Schnoelzer, and H.L. Saenger. 1985. Molecular cloning of potato spindle tuber viroid (PSTV) cDNA synthesized by enzymic elongation of PSTV-specific DNA primers: a general strategy for viroid cloning. Biosci. Rep. 5: 143158.

Wang, M.J., N.W. Davis, and P. Gegenheimer. 1988. Novel mechanisms for maturation of chloroplașt transfer RNA precursors. EMBO /. 7: 1567-1574. 


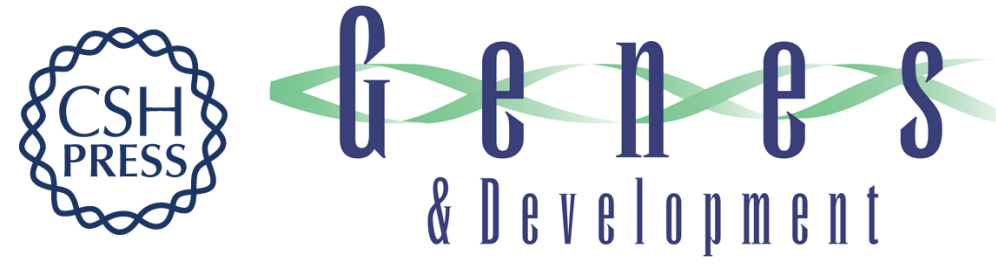

\section{Identification and characterization of an RNA molecule that copurifies with RNase $P$ activity from HeLa cells.}

M Bartkiewicz, H Gold and S Altman

Genes Dev. 1989, 3:

Access the most recent version at doi:10.1101/gad.3.4.488

References This article cites 29 articles, 4 of which can be accessed free at: http://genesdev.cshlp.org/content/3/4/488.full.html\#ref-list-1

License

Email Alerting

Service

Receive free email alerts when new articles cite this article - sign up in the box at the top right corner of the article or click here.

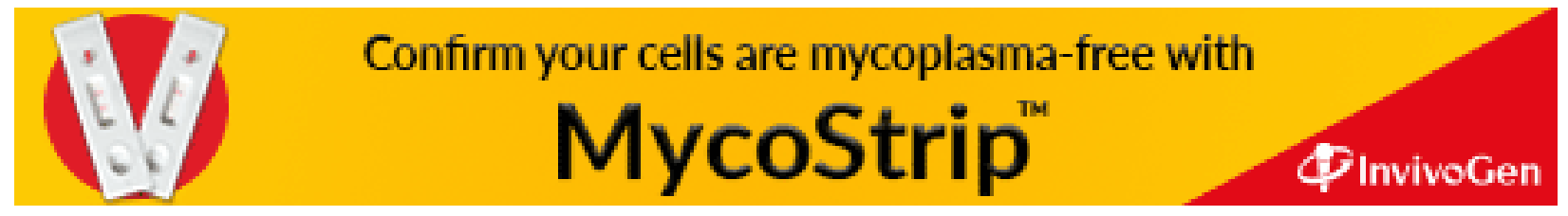

